\title{
Impact of mesospheric intrusions on ozone-tracer relations in the stratospheric polar vortex
}

\author{
Rolf Müller, ${ }^{1}$ Simone Tilmes, ${ }^{2}$ Jens-Uwe Grooß, ${ }^{1}$ Andreas Engel, ${ }^{3}$ Hermann Oelhaf, ${ }^{4}$ \\ Gerald Wetzel, ${ }^{4}$ Nathalie Huret, ${ }^{5}$ Michel Pirre, ${ }^{5}$ Valéry Catoire, ${ }^{5}$ Geoff Toon, ${ }^{6}$ \\ and Hideaki Nakajima ${ }^{7}$
}

Received 5 December 2006; revised 13 August 2007; accepted 29 August 2007; published 13 December 2007.

[1] Ozone-tracer relations are used to quantify chemical ozone loss in the polar vortices. The underlying assumptions for the application of this technique were extensively discussed in recent years. However, the impact intrusions of mesospheric air into the polar stratosphere have on estimates of chemical ozone loss based on the ozone-tracer technique has not hitherto been studied. Here, we revisit observations of an intrusion of mesospheric air down to altitudes of $\sim 25 \mathrm{~km}(\sim 600 \mathrm{~K}$ potential temperature $)$ in the Arctic vortex in 2003. The mesospheric intrusion was identified in three balloon profiles in January and March 2003 as a strong enhancement in CO. In contrast, $\mathrm{NO}_{y}$ was not enhanced in the mesospheric air relative to surrounding air masses as shown by the measurement in late March 2003. The measurements influenced by mesospheric air show ozone mixing ratios ranging between 3.6 and $5.6 \mathrm{ppm}$, which are clearly greater than those found in the "early vortex" reference relation employed to deduce chemical ozone loss. Thus the impact of intrusions of mesospheric air into the polar vortex on chemical ozone loss estimates based on ozone-tracer relations are likely small; the correlations cannot be affected in a way that would lead to an overestimate of ozone depletion. Therefore ozone-tracer relations may be used for deducing chemical ozone loss in Arctic winter 2002-2003. Here we use ILAS-II satellite measurements to deduce an average chemical ozone loss in the vortex core for the partial column $380-550 \mathrm{~K}$ of $37 \pm$ 11 Dobson units in March and of $50 \pm 10$ Dobson units in April 2003.

Citation: Müller, R., et al. (2007), Impact of mesospheric intrusions on ozone-tracer relations in the stratospheric polar vortex, J. Geophys. Res., 112, D23307, doi:10.1029/2006JD008315.

\section{Introduction}

[2] Observations of the relation between ozone and longlived tracers have been used extensively in recent years as a tool for analyzing and quantifying chemical ozone loss in the polar vortices [e.g., Rex et al., 2002; Salawitch et al., 2002; Tilmes et al., 2004, 2006a, 2006b]. An important issue regarding the applicability of this methodology is the question of the extent to which mixing across the vortex

\footnotetext{
${ }^{1}$ Institute for Stratospheric Chemistry, Forschungszentrum Jülich, Jülich, Germany

${ }^{2}$ Atmospheric Chemistry Division, National Center for Atmospheric Research, Boulder, Colorado, USA.

${ }^{3}$ Institut für Atmosphäre und Umwelt, Johann Wolfgang GoetheUniversität, Frankfurt, Germany.

${ }^{4}$ Institut für Meteorologie und Klimaforschung, Forschungszentrum Karlsruhe, Karlsruhe, Germany.

${ }^{5}$ Laboratoire de Physique et Chimie de l'Environnement, CNRS, Orléans, France.

${ }^{6}$ Jet Propulsion Laboratory, California Institute of Technology, Pasadena, USA.

${ }^{7}$ Atmospheric Environment Division, National Institute for Environmental Studies, Tsukuba, Japan.
}

Copyright 2007 by the American Geophysical Union. 0148-0227/07/2006JD008315 edge [Michelsen et al., 1998; Plumb et al., 2000] or differential descent with subsequent mixing within the vortex [Salawitch et al., 2002] may impact ozone-tracer relations in the vortex. A change in ozone-tracer relations because of mixing in the absence of chemical change could in principle lead to either an overestimate or an underestimate of chemical ozone loss. Tilmes et al. [2004] and Müller et al. [2005] have discussed this issue in detail and concluded that mixing across the polar vortex edge may impact ozone-tracer relations in the vortex solely in a way that leads to an underestimation of chemical ozone loss and that differential descent in the vortex with subsequent internal mixing within the vortex has only a negligible effect on ozone loss estimates.

[3] Recently, Lemmen et al. [2006b] showed that ozonetracer relations may also be used to deduce the chemical ozone loss as simulated in Chemistry Climate Models (CCMs) where mixing across the vortex edge is very likely stronger than in the real atmosphere. Using this technique, it has been shown that chemical ozone loss in the Antarctic vortex is underestimated in the ECHAM4.DLR(L39)/ CHEM model [Lemmen et al., 2006a]. Tilmes et al. [2007] analyzed results of the Whole Atmosphere Community Climate Model (WACCM) using ozone-tracer relations 
and found that chemical ozone loss can be reproduced in the core of the Antarctic vortex but that it is underestimated in the outer vortex.

[4] Here we analyze ozone-tracer relations in the Arctic winter 2002/2003, when an intrusion of mesospheric air into the stratosphere was observed [Engel et al., 2006; Huret et al., 2006]. (Note that the term "intrusion" is used here in a different sense than quasi-isentropic filamentary intrusions into the vortex from the extratropics, a concept that frequently also appears in the literature.) The meteorological situation of this winter is described in detail elsewhere [e.g., Tilmes et al., 2003a; Groo $\beta$ et al., 2005; Streibel et al., 2006]. During this winter, the polar vortex twice split into two separate parts, from 19 to 21 January and again later between 16 and 21 February 2003 and, in both cases, was reunified within a few days after the split. The vortex remained compact during March and the first part of April, before it broke down in late April. We will both investigate the impact of the mesospheric intrusion on stratospheric tracer-tracer relations and also deduce chemical ozone loss based on ozone-tracer relations from the measurements of the ILAS-II (Improved Limb Atmospheric Spectrometer-II) instrument aboard ADEOS-II (Advanced Earth Observing Satellite-II) [Nakajima et al., 2006].

[5] The mesospheric intrusion may be identified as strongly enhanced $\mathrm{CO}$ mixing ratios. It occurred in the Arctic vortex in early 2003 in a layer descending from $\sim 30 \mathrm{~km}$ in late January to $\sim 25 \mathrm{~km}$ by early March [Engel et al., 2006; Huret et al., 2006]. This mesospheric air was sampled again in the vortex in late March [Engel et al., 2006; Wetzel et al., 2006]. Strongly enhanced values of CO of mesospheric origin down to $30 \mathrm{~km}$ were also observed in mid-January 2003 by a ground-based millimeter wave spectrometer [de Zafra and Muscari, 2004]. These observations are further consistent with $\mathrm{CO}$ measurements from the MIPAS-Envisat instrument with a vertical resolution of $\sim 8 \mathrm{~km}$ [Funke et al., 2006 that show enhanced $\mathrm{CO}$ down to about $600 \mathrm{~K}$ in March 2003 [Konopka et al., 2007]. The penetration of mesospheric air to lower altitudes in the Arctic in 2003, however, did not lead to a noticeable enhancement of $\mathrm{CO}$ column densities [Velazco et al., 2007].

[6] Engel et al. [2006] raised the question of whether the presence of a substantial amount of mesospheric air in the polar vortex may impact the uncertainty of estimates of chemical polar ozone loss using ozone-tracer relations. Because ozone mixing ratios in the mesosphere (typically less than $\sim 2 \mathrm{ppm}$ ) are lower than those in the stratosphere, mixing of mesospheric and lower stratospheric air could potentially impact ozone tracer relations in a way that would lead to an overestimation of chemical ozone loss deduced from tracer relations. (Here and throughout the paper, we use the abbreviations ppm (parts per million) and ppb (parts per billion) to denote molar mixing ratios.) Also, indeed, intrusions of mesospheric air into the stratosphere have been observed on various occasions [e.g., Kouker et al., 1995; Rinsland et al., 1999; Ray et al., 2002; Curtius et al., 2005; Engel et al., 2006; Randall et al., 2006]. This question has not hitherto been studied.

[7] Here, we address this question revisiting the observations in the Arctic vortex in early 2003. The intrusion of mesospheric air was clearly identified in three balloonborne measurements in January and March 2003 as strongly enhanced $\mathrm{CO}$ mixing ratios. This mesospheric intrusion did not, however, show enhanced values of $\mathrm{NO}_{y}$ as they have been reported for other years [e.g., Randall et al., 2005; World Meteorological Organisation (WMO), 2007]. Further, we find that in the ozone- $\mathrm{CH}_{4}$ and ozone- $\mathrm{N}_{2} \mathrm{O}$ relations the measurements influenced by mesospheric air do not show unusually low ozone mixing ratios in any of the three balloon profiles measured in the vortex in early 2003 . Rather, ozone mixing ratios in these air masses range between 3.6 and $5.6 \mathrm{ppm}$, which are clearly greater than typical mesospheric ozone mixing ratios and indeed lower stratospheric ozone mixing ratios in the polar vortex. Therefore we conclude that intrusions of mesospheric air into the polar vortex cannot impact ozone-tracer relations in a way that would lead to an overestimate of ozone depletion deduced by the tracer correlation method.

\section{Climatology of Ozone-Tracer Relations in the Middle Atmosphere}

[8] Mesospheric air, located above the ozone maximum, shows a very different ozone-tracer relation than lower stratospheric air [e.g., Michelsen et al., 1998]. Ozone and long-lived tracers with a tropospheric source (e.g., $\mathrm{CH}_{4}$ or $\mathrm{N}_{2} \mathrm{O}$ ) are correlated in mesospheric air whereas they are anticorrelated in the lower stratosphere. Therefore, in the tropics and the midlatitudes, a "mountain-shaped" ozonemethane relation develops (Figure 1). In the tropics, the maximum ozone mixing ratios are greater than at midlatitudes and the maximum ozone corresponds to higher mixing ratios of methane. This is so, because in the tropics substantial ozone production via the photolysis of molecular oxygen begins at altitudes $(\sim 30 \mathrm{hPa})$ when the stratospheric air is rather young so that methane mixing ratios are still large, close to tropospheric mixing ratios. In the midlatitudes, the stratospheric air is older and thus methane mixing ratios are lower than in the tropics at the altitudes where the maximum ozone occurs (Figure 1).

[9] In the polar regions, the ozone-tracer relations are more complex. In late November or early December, a distinct "early vortex" ozone-tracer relation develops in the Arctic vortex [e.g., Müller et al., 1996; Tilmes et al., 2003b, 2004]. Such relations are similar to the climatological January relation (Figure 2, top), but differ from winter to winter [see Tilmes et al., 2004, Figures 4 and 5].

[10] In late winter and early spring, the vortex breaks down starting from the top [e.g., Harvey et al., 2002; Manney et al., 2005] which means that in the vortex in the upper stratosphere and lower mesosphere both ozone and methane increase as air, rich in ozone and methane, is mixed in from lower latitudes. A mixing zone develops at the interface between the mesospheric air with a positive ozone-methane correlation and the stratospheric vortex air (which shows relatively low ozone mixing ratios) with a negative ozone-methane correlation. In this way, a "thumbshaped" ozone-tracer relation (Figure 2) develops [see also Plumb et al., 2000, Plate 1].

[11] In the Arctic, the vortex in the upper stratosphere is perturbed owing to the occurrence of midwinter wave events [Waugh and Randel, 1999; Steinhorst et al., 2005]. Therefore this thumb-shaped ozone-tracer relation prevails in the Arctic between February and April and becomes more 


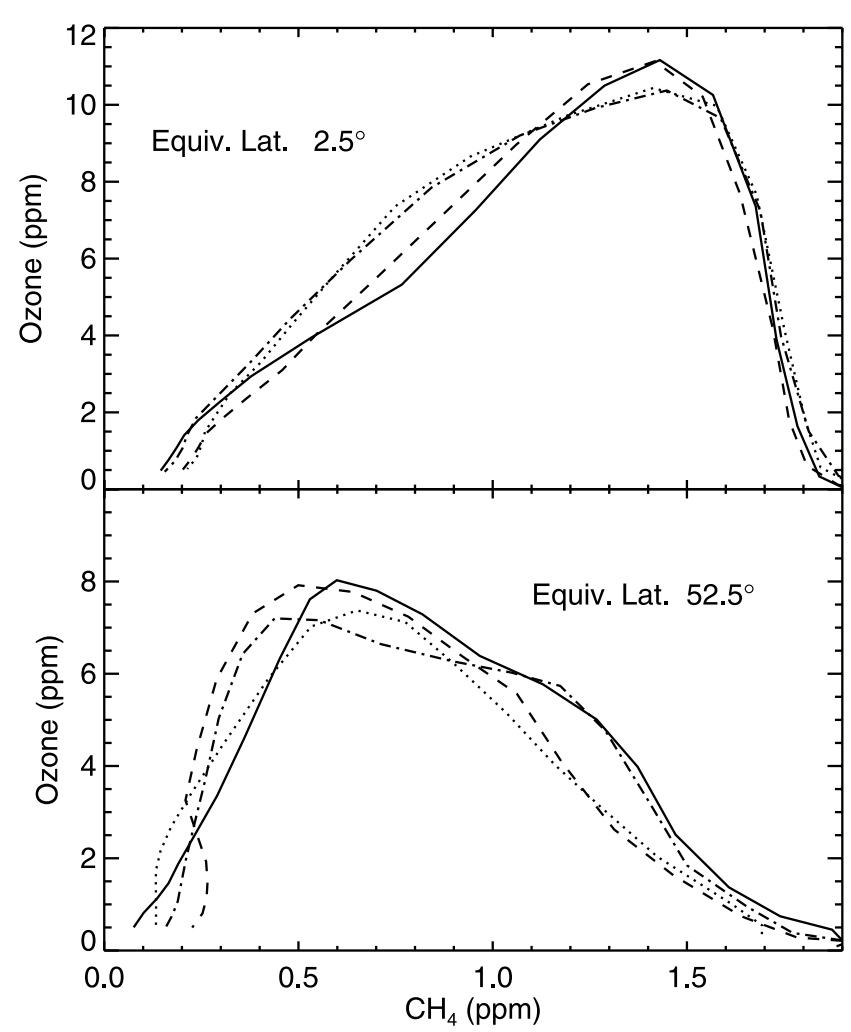

Figure 1. Methane-ozone relation at (top) $2.5^{\circ} \mathrm{N}$ and (bottom) $52.5^{\circ} \mathrm{N}$ from a climatology based on HALOE measurements [Groo $\beta$ and Russell, 2005]. Solid lines show data for March, dotted lines show data for June, dashed lines show data for September, and dash-dotted lines show data for December.

and more pronounced (Figure 2, top). By June (not shown), the vortex and thus the signature of ozone-poor vortex air has disappeared and a mountain-shaped ozone-tracer relation is reestablished.

[12] In the Antarctic, in contrast, the vortex has a longer life span than in the Arctic and the vortex breaks down more than a month later than its Arctic counterpart [Waugh and Randel, 1999]. This difference in the dynamics of the Arctic and Antarctic polar vortex is the reason for the observed differences in the ozone-methane relations. The Antarctic ozone-methane relation in the vortex through winter and early spring (from June to September) is rather stable (Figure 2, bottom). Only continuously decreasing ozone mixing ratios (due to chemical ozone loss) within the polar vortex are obvious. The effect of the polar vortex breakdown from the top, resulting in the thumb-shaped ozonetracer relation (not shown) occurs later in the season, in November/December (corresponding to May/June in the northern hemisphere). For the Antarctic, the mountainshaped ozone-tracer relation is only reestablished by January (not shown).

[13] When interpreting Figures 1 and 2, it must be taken into account that ozone and methane can no longer be considered tracers in the mesosphere (e.g., at $70 \mathrm{~km}$ the lifetime of methane and $\mathrm{N}_{2} \mathrm{O}$ is $\sim 1$ month, the lifetime of ozone is about an hour). Therefore the tracer relations in Figures 1 and 2 at mesospheric altitudes are only valid in a climatological sense, particular measurements will not show compact relations.

[14] A reduction of ozone mixing ratios in the lower stratosphere by mixing with mesospheric air is not noticeable in the climatological ozone-methane relation in polar regions. However, specific events such as the intrusion of mesospheric air into the Arctic stratosphere in 2003 reported by Engel et al. [2006] cannot be resolved in a climatological data set. This issue is addressed in section 3 .

\section{Arctic Polar Vortex in Winter 2002/2003}

[15] In Arctic winter 2002/2003, four balloon-borne measurements of the ozone-tracer relation were made in the lower stratosphere [Tilmes et al., 2003a; Engel et al., 2006; Huret et al., 2006; Wetzel et al., 2006]. Here we revisit this set of measurements focusing on the identification of air masses of mesospheric origin. This mesospheric air has "intruded" into the stratosphere meaning that the air above and below the layer of mesospheric air is "younger" than the mesospheric air. However, the mesospheric air has not reached the stratosphere unmixed and chemical change has occurred during descent.

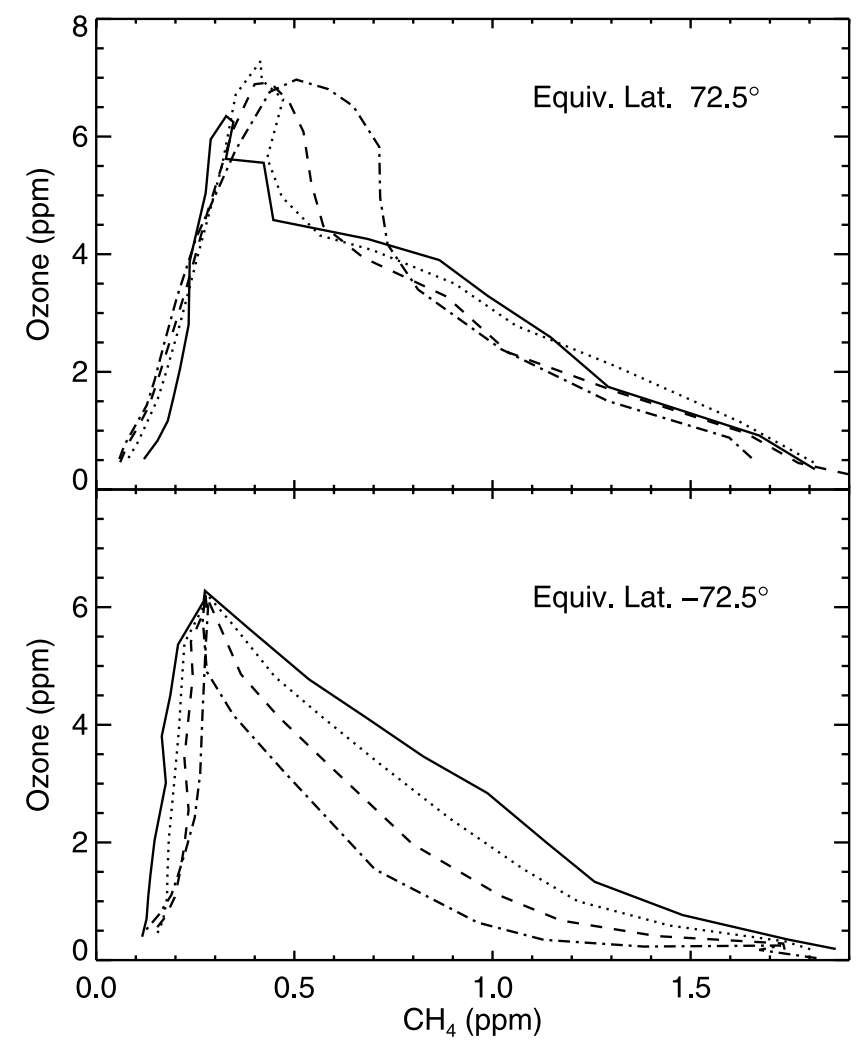

Figure 2. Similar to Figure 1 but for the polar regions in winter and spring. Methane-ozone relation at (top) $72.5^{\circ} \mathrm{N}$ and (bottom) $-72.5^{\circ} \mathrm{N}$. In Figure 2 (top), the solid line shows data for January, the dotted line shows data for February, the dashed line shows data for March, and the dash-dotted line shows data for April. In Figure 2 (bottom), the solid line shows data for June, the dotted line shows data for July, the dashed lines show data for August, and dashdotted line shows data for September. 

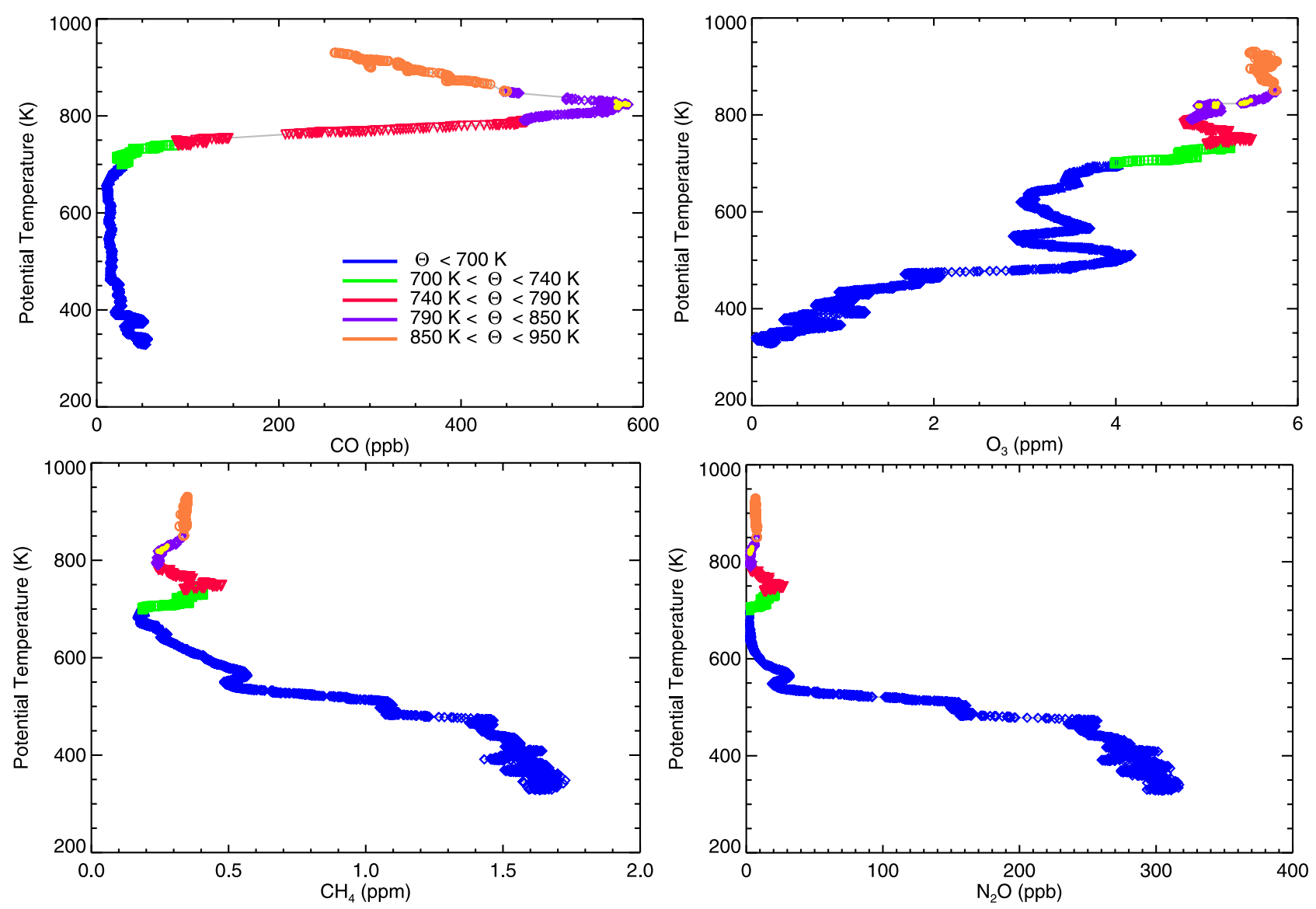

Figure 3. Vertical profile of (top left) $\mathrm{CO}$, (top right) ozone, (bottom left) methane, and (bottom right) $\mathrm{N}_{2} \mathrm{O}$ from the SPIRALE measurements on 21 January 2003. The measurements are color-coded according to altitude (see color legend in Figure 3, top left). Air masses that are most strongly influenced by mesospheric air (CO ranging between 570 and $584 \mathrm{ppb}$ ) are marked by solid yellow circles.

\subsection{Mixing Patterns in the SPIRALE Measurements on 21 January 2003}

[16] On 21 January 2003, balloon-borne measurements by SPIRALE of a variety of species were taken with a very high vertical resolution [Huret et al., 2006]; here we show the mixing ratios of $\mathrm{CO}$, ozone, methane, and nitrous oxide against potential temperature (Figure 3). An intrusion of mesospheric air and the signature of mixing between (stratospheric) midlatitude air and mesospheric air within the polar vortex were clearly identified [Huret et al., 2006]. The mesospheric intrusion is most obvious as a layer with strongly enhanced $\mathrm{CO}$ mixing ratios (Figure 3 ).

[17] The high vertical resolution of SPIRALE allows a detailed analysis of the complexity of the mixing patterns. Below $700 \mathrm{~K}$ (blue symbols in Figures 3 and 4) the measurements are taken within the polar vortex (sometimes close to the vortex edge). The $\mathrm{CH}_{4}-\mathrm{N}_{2} \mathrm{O}$ relation measured by SPIRALE is a typical vortex relation, it agrees with earlier ATMOS measurements [Michelsen et al., 1998] of this relation in the polar vortex (as has been shown by Huret et al. [2006]) and with the BONBON measurements on 6 March 2003 that are not influenced by mesospheric air (gray squares in Figure 4, bottom). Note that a typical midlatitude $\mathrm{CH}_{4}-\mathrm{N}_{2} \mathrm{O}$ relation (gray line in Figure 4, bottom) is clearly distinct from the polar relation measured by
SPIRALE. Likewise, the ozone-methane relation below $700 \mathrm{~K}$ (blue symbols in Figure 4, top) agrees with an early vortex reference deduced from MkIV measurements on 16 December 2002 [Tilmes, 2004].

[18] In the layer between $700 \mathrm{~K}$ and $740 \mathrm{~K}$ (green symbols in Figures 3 and 4) stratospheric vortex air is mixed with midlatitude stratospheric air. $\mathrm{CO}$ mixing ratios in this layer are relatively low, below $100 \mathrm{ppb}$ (Figure 3). Mixing of vortex and out-of-vortex air masses leads to mixing lines toward air with greater ozone and greater tracer mixing ratios, i.e., air of midlatitude characteristics [e.g., Müller et al., 2005]. This effect is clearly noticeable in the SPIRALE measurements of the ozone-methane relation (Figure 4, top, green symbols). The effect of mixing is also noticeable in the $\mathrm{CH}_{4}-\mathrm{N}_{2} \mathrm{O}$ relation (Figure 4, top); extrapolating the approximately linear mixing line leads to a midlatitude endpoint of $\sim 0.85 \mathrm{ppm} \mathrm{CH}_{4}$ and $70 \mathrm{ppb} \mathrm{N}_{2} \mathrm{O}$.

[19] Above $740 \mathrm{~K}$, the mesospheric influence increases and $\mathrm{CO}$ mixing ratios exceed $100 \mathrm{ppb}$. The layer between $740 \mathrm{~K}$ and $790 \mathrm{~K}$ (red symbols) consists of a mixture of mesospheric air masses (characterized by large CO mixing ratios) with midlatitude air (characterized by larger tracer values). Both the layers between $700-740 \mathrm{~K}$ and $740-790 \mathrm{~K}$ are strongly mixed, as can be seen from the $\mathrm{CH}_{4}-\mathrm{N}_{2} \mathrm{O}$ relation that is practically linear in both cases (Figure 4). However, the two mixing lines can be clearly distinguished, 

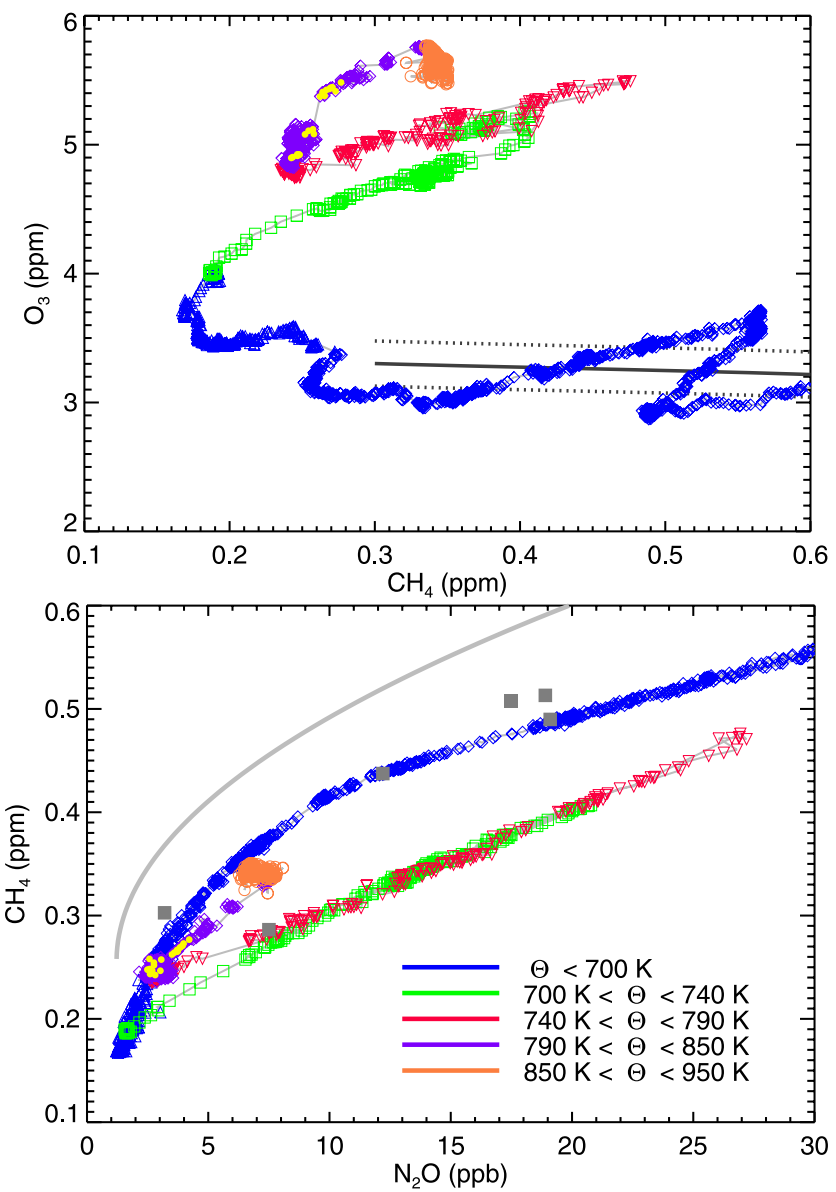

Figure 4. (top) Ozone-methane and (bottom) methane- $\mathrm{N}_{2} \mathrm{O}$ relation from the SPIRALE measurements on 21 January 2003. The measurements are color coded according to altitude as in Figure 3 (color legend in Figure 4, bottom). Air masses that are most strongly influenced by mesospheric air ( $\mathrm{CO}$ ranging between 570 and $584 \mathrm{ppb}$ ) are marked by solid yellow circles. Gray squares in Figure 4 (bottom) show the BONBON measurements on 6 March 2003 that are not influenced by mesospheric air. The gray solid line in Figure 4 (bottom) indicates the methane- $\mathrm{N}_{2} \mathrm{O}$ relation for midlatitudes reported by Michelsen et al. [1998] adjusted to 2003 conditions by increasing $\mathrm{N}_{2} \mathrm{O}$ by $2.3 \%$ and $\mathrm{CH}_{4}$ by $3.2 \%$. The black solid line in Figure 4 (top) shows an early vortex reference deduced from MkIV measurements on 16 December 2002 [Tilmes, 2004], and dotted lines show the uncertainty of the reference.

especially in the ozone- $\mathrm{CH}_{4}$ relation (Figure 4, top). Note that one BONBON data point (the one taken at $23.9 \mathrm{~km}$, $598 \mathrm{~K}$ ) is located on a mixing line, indicating that a mixed air mass was sampled in this case as well. A similar case of mixing between vortex air and out-of-vortex air masses that led to a linear $\mathrm{CH}_{4}-\mathrm{N}_{2} \mathrm{O}$ relation has been reported by Rex et al. [1999] based on high-altitude aircraft measurements in the Arctic on 26 April 1997.

[20] Between $790 \mathrm{~K}$ and $850 \mathrm{~K}$ (purple symbols), the largest $\mathrm{CO}$ mixing ratios occur, which indicates that this air is most strongly influenced by mesospheric air. The air masses at the top of the SPIRALE profile, above $850 \mathrm{~K}$ (orange symbols) show lower $\mathrm{CO}$ mixing ratios and therefore less mesospheric influence. Indeed the $\mathrm{CH}_{4}-\mathrm{N}_{2} \mathrm{O}$ relation of these air masses becomes similar to the undisturbed vortex relation (blue symbols) again.

[21] In Figure 4, it can be seen that the mixing lines in the air mass below the mesospheric layer are much longer than those in the air mass above. We offer as an explanation the fact that the air mass below the mesospheric layer was mixed with midlatitude air. In contrast, the air mass above the mesospheric layer was mixed with vortex air with a different descent rate [Huret et al., 2006]. Therefore the mixing line in the air mass below the mesospheric layer "aims" at an air mass farther away in tracer-tracer space.

\subsection{Detection of Mesospheric Air in the MIPAS-B Measurements on 20 March 2003}

[22] The MIPAS-B instrument [Friedl-Vallon et al., 2004] took measurements inside the polar vortex on 20 March 2003. In a layer between 21 and $23 \mathrm{~km}$, substantially greater $\mathrm{NO}_{y}$ (by $\sim 30 \%$ ) was found than predicted from a $\mathrm{NO}_{y}-\mathrm{N}_{2} \mathrm{O}$ reference for undisturbed winter conditions, according to the MIPAS data set analyzed by [Engel et al., 2006]. Production of $\mathrm{NO}$ from $\mathrm{N}_{2}$ in the upper atmosphere may indeed lead to enhancement of $\mathrm{NO}_{y}$ in the mesosphere and in the stratosphere [e.g., Vitt et al., 2000; WMO, 2007]. Therefore Engel et al. [2006] attributed this enhanced $\mathrm{NO}_{y}$ to enhanced NO in mesospheric air and concluded that at $\sim 22 \mathrm{~km}$ MIPAS-B had sampled the descending layer of mesospheric air in the Arctic vortex in early 2003.

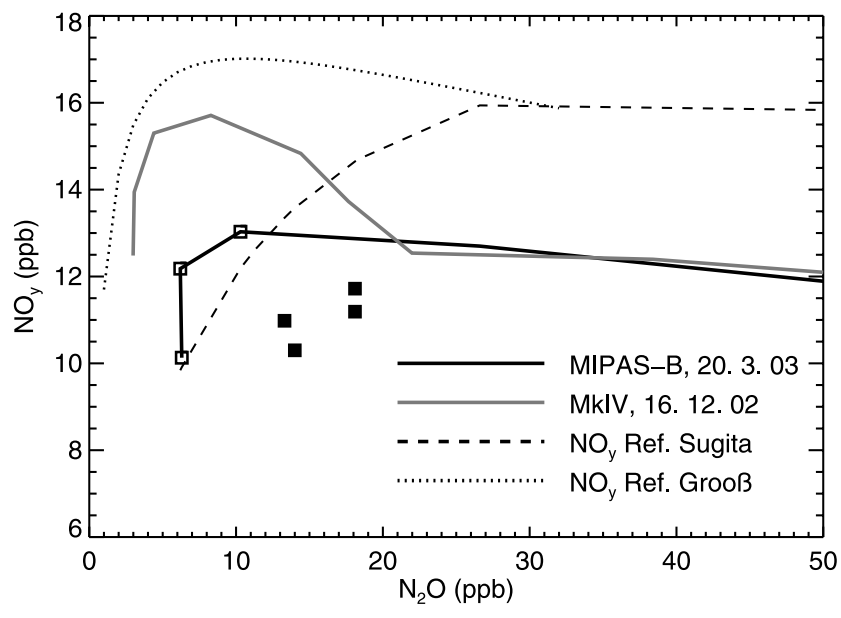

Figure 5. Relation of $\mathrm{NO}_{y}$ and $\mathrm{N}_{2} \mathrm{O}$ (thick black line and squares) from the MIPAS-B measurements on 20 March 2003 in the polar vortex. Open squares indicate measurements (at $21-23 \mathrm{~km}$ ) taken in mesospheric air according to Engel et al. [2006]; here the samples between 24 and $27 \mathrm{~km}$ (solid squares) are identified as of mesospheric origin (see text); the thick black line shows the measurements below $24 \mathrm{~km}$. Also shown are $\mathrm{NO}_{y}-\mathrm{N}_{2} \mathrm{O}$ from the $\mathrm{MkIV}$ measurement on 16 December 2002 (thick gray line), the $\mathrm{NO}_{y}-\mathrm{N}_{2} \mathrm{O}$ reference for midlatitude conditions based on atmospheric trace molecule spectroscopy (ATMOS) measurements reported by Sugita et al. [1998] (dashed black line), and the $\mathrm{NO}_{y}-\mathrm{N}_{2} \mathrm{O}$ reference deduced for winter 2002/ 2003 by Grooß et al. [2005] (dotted line). 
[23] Here, we consider a reanalyzed MIPAS-B data set that was produced with improved spectroscopic parameters [Rothman et al., 2005]. (The vertical profiles of $\mathrm{N}_{2} \mathrm{O}, \mathrm{CH}_{4}$, and ozone are shown in the auxiliary material). ${ }^{1}$ The MIPAS $\mathrm{NO}_{y}$ values changed significantly (by up to $1 \mathrm{ppb}$ ) due to the improved spectroscopic parameters, so that it is not straightforward to compare these data with previously reported $\mathrm{NO}_{y}-\mathrm{N}_{2} \mathrm{O}$ reference relations. Compared to a $\mathrm{NO}_{y}-\mathrm{N}_{2} \mathrm{O}$ reference for midlatitude conditions based on atmospheric trace molecule spectroscopy (ATMOS) measurements reported by Sugita et al. [1998] (black dashed line in Figure 5), the $\mathrm{NO}_{y}$ in the layer 21-23 km (open squares in Figure 5) on 20 March 2003 is somewhat enhanced.

[24] However, the $\mathrm{NO}_{y}$ measured by MIPAS-B on 20 March 2003 between 21 and $23 \mathrm{~km}$ is not enhanced compared to the $\mathrm{NO}_{y}-\mathrm{N}_{2} \mathrm{O}$ relation from the MkIV measurement on 16 December 2002 (thick gray line in Figure 5). At lower altitudes, below about $26 \mathrm{~km}$ (corresponding to $650 \mathrm{~K}$, $\mathrm{N}_{2} \mathrm{O}=15 \mathrm{ppb}$ ) the MkIV measurements show signs of early denitrification [Grooß et al., 2005]. Therefore we also show a $\mathrm{NO}_{y}-\mathrm{N}_{2} \mathrm{O}$ reference derived to describe unperturbed conditions in winter 2002/2003 (dotted line in Figure 5 [Grooß et al., 2005]). This relation supports the interpretation that $\mathrm{NO}_{y}$ is not enhanced in the layer $21-23 \mathrm{~km}$ on 20 March 2003.

[25] Strong enhancements of $\mathrm{NO}_{x}$ are intermittently observed which are caused by unusually strong energetic parcel precipitation or by solar proton events [Randall et al., 2005; López-Puertas et al., 2005; Jackman et al., 2006; $W M O, 2007]$. Such conditions did not prevail in Arctic winter 2002/2003. In contrast, findings based on MIPASEnvisat measurements [Funke et al., 2005] suggest that in Arctic winter 2002/2003 rather inefficient $\mathrm{NO}_{x}$ downward transport occurred with negligible deposition of $\mathrm{NO}_{x}$ into the lower and middle stratosphere. Further, model studies [Vitt et al., 2000] predict that the enhancement of the $\mathrm{NO}_{y}$ budget in the stratosphere caused by thermospheric $\mathrm{NO}_{x}$ sources is rather moderate, about 3\% and $8 \%$ in the northern and southern polar region, respectively. In the south polar night, the simulated enhancement at $\sim 30 \mathrm{~km}$ is $10 \%$, although the enhancement strongly increases with altitude [Vitt et al., 2000].

[26] In contrast to the measurements between 21 and 23 $\mathrm{km}$, the MIPAS measurements at $24-27 \mathrm{~km}$ (solid squares) clearly deviate from all $\mathrm{NO}_{y}-\mathrm{N}_{2} \mathrm{O}$ relations shown in Figure 5. Further, in late March, the mesospheric air will be mixed with stratospheric air, so that the mesospherically influenced points are expected to lie on a "mixing line" between mesospheric and stratospheric air. (Here, the concept of a mixing line is an idealization; the mixing between mesospheric and stratospheric air will certainly not occur in one single event.) Indeed, the location of the measurements at $24-27 \mathrm{~km}$ (solid squares in Figure 5) in the $\mathrm{NO}_{y}-\mathrm{N}_{2} \mathrm{O}$ scatterplot is consistent with the assumption that these points are influenced by mixing.

[27] Although it is a difficult retrieval, $\mathrm{CO}$ mixing ratios can be deduced from MIPAS-B spectra (Figure 6). There is a clear peak in $\mathrm{CO}$ noticeable in the layer at $24-27 \mathrm{~km}$, where the values exceed $100 \mathrm{ppb}$. This observation corrob-

${ }^{1}$ Auxiliary materials are available in the HTML. doi:10.1029/ 2006JD008315.

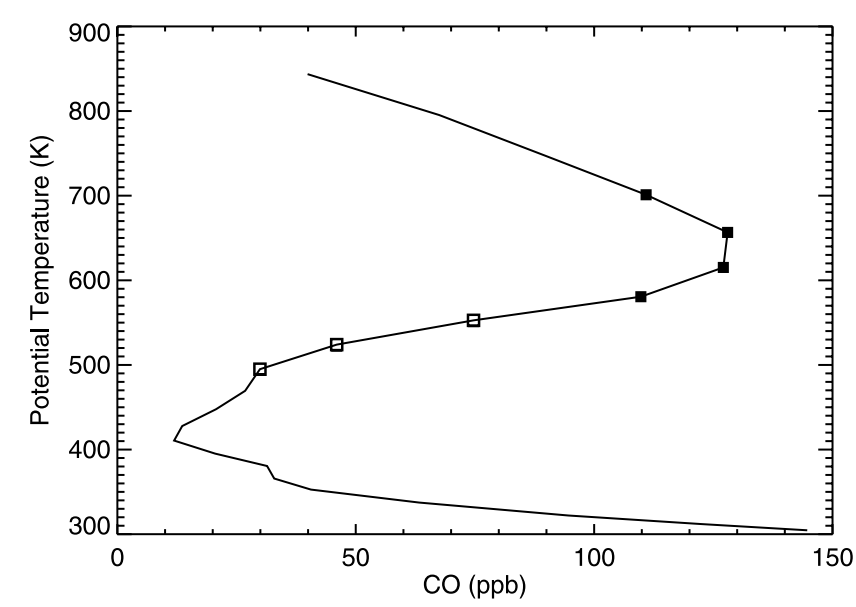

Figure 6. $\mathrm{CO}$ mixing ratio plotted against potential temperature on 20 March 2003 inside the vortex measured by MIPAS-B. Solid squares (corresponding to $24-27 \mathrm{~km}$ ) indicate measurements identified as being under mesospheric influence owing to the elevated $\mathrm{CO}$ mixing ratio. Open squares (corresponding to $21-23 \mathrm{~km}$ ) indicate the measurements considered as mesospheric in an earlier publication [Engel et al., 2006].

orates the interpretation that the layer at $24-27 \mathrm{~km}$ is influenced by mesospheric air.

[28] On the basis of the body of evidence discussed above, we conclude here that the mesospheric layer was sampled by MIPAS-B on 20 March 2003 at $24-27 \mathrm{~km}$ altitude. This attribution agrees with the prediction by the KASIMA model of the location of the mesospheric layer in late March 2003 [Engel et al., 2006].

\subsection{Balloon-Borne Observations of Ozone-Tracer Relations in Winter 2002/2003}

[29] The measurements of the ozone-tracer relation from the four balloon flights in Arctic winter 2002/2003 are shown in Figure 7. The measurements by the MkIV instrument [Toon et al., 1999] on 16 December 2002 (open diamonds in Figure 7) show a rather typical early vortex relation [Tilmes et al., 2003a, 2004]. At the top of the MkIV profile (above $750 \mathrm{~K}$, not shown) maximum HF mixing ratios occur, $\mathrm{SF}_{6}$ mixing ratios are $3.2-3.4 \mathrm{ppt}$, and the $\mathrm{CO}$ mixing ratio at the top altitude is $35 \mathrm{ppb}$; all these values are typical of upper stratospheric air.

[30] The ozone- $\mathrm{N}_{2} \mathrm{O}$ relation measured by SPIRALE on 21 January 2003 (thick gray line in Figure 7 [Huret et al., 2006]), agrees with the MkIV relation in parts of the profile but also shows deviations toward greater ozone and greater tracer mixing ratios that are indicative of mixing of polar with midlatitude air [e.g., Müller et al., 2005]. Indeed, the enhancement of ozone at around $100 \mathrm{ppb} \mathrm{N}_{2} \mathrm{O}$, where $\mathrm{O}_{3}$ exceeds $4 \mathrm{ppm}$, occurs at $\sim 500 \mathrm{~K}$ where SPIRALE sampled the vortex edge region [Huret et al., 2006]. At greater altitudes, complex mixing patterns developed between mesospheric air and stratospheric air of vortex and midlatitude origin (see discussion in section 3.1).

[31] The ozone- $\mathrm{N}_{2} \mathrm{O}$ relation measured by BONBON on 6 March 2003 in the lower stratosphere [Engel et al., 2006] shows lower ozone mixing ratios than the MkIV relation 

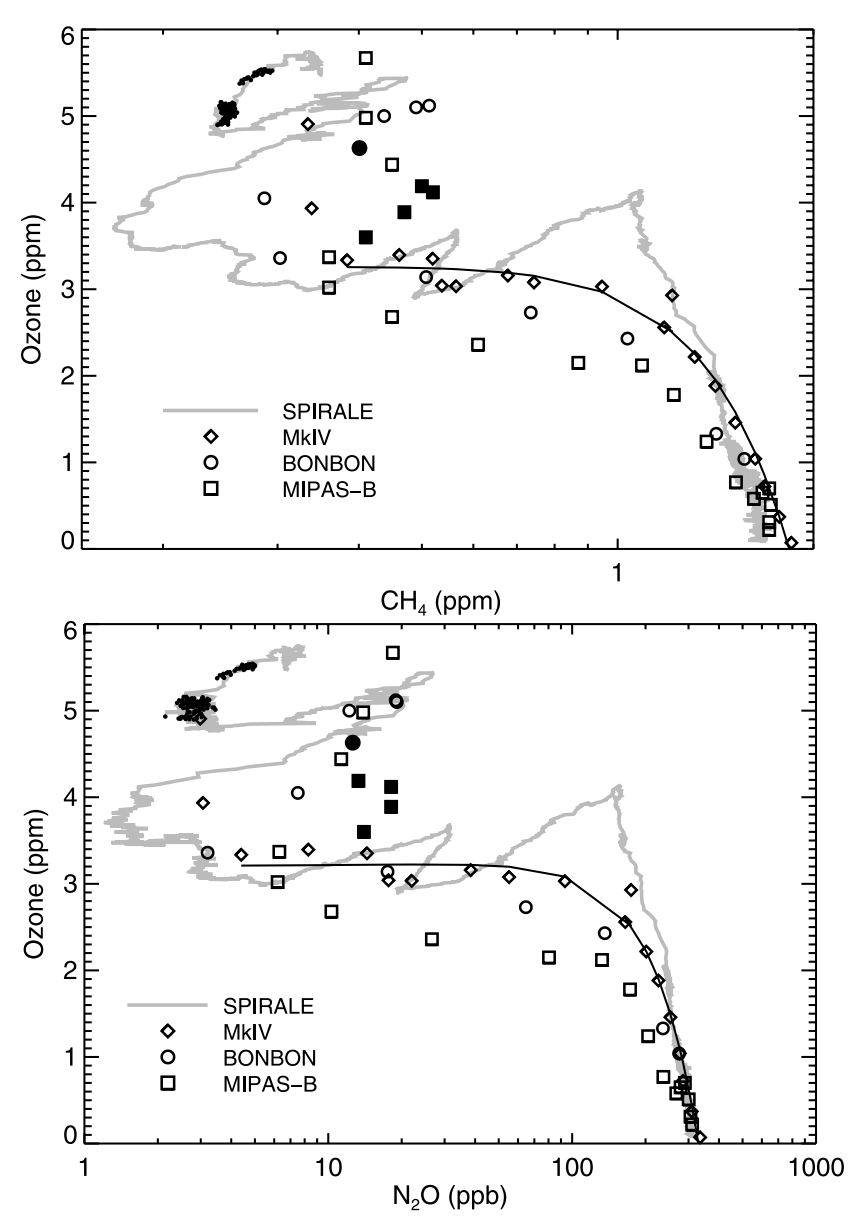

Figure 7. (top) Ozone-methane and (bottom) ozone- $\mathrm{N}_{2} \mathrm{O}$ relation from balloon measurements in the Arctic polar vortex on 20 March 2003 (from MIPAS, squares [Wetzel et al., 2006]), on 6 March 2003 (from BONBON, circles [Engel et al., 2006]), on 21 January 2003 (from SPIRALE, thick gray line [Huret et al., 2006]), and on 16 December 2002 (from MkIV, diamonds [Tilmes et al., 2003a]). Measurements in the mesospheric air mass in January (CO mixing ratios greater than $570 \mathrm{ppb}$ ) and in March 2003 are shown as solid symbols. Note the logarithmic scaling of the $x$ axis. The solid black lines show an empirical fit through the stratospheric measurements on 16 December 2002; Figure 7 (top) shows the ozone-methane relation reported by Tilmes et al. [2003a] and Figure 7 (bottom) shows the empirical relation $\mathrm{O}_{3}=3.20+1.47 \times 10^{-3} \times$ $\mathrm{N}_{2} \mathrm{O}-2.80 \times 10^{-5} \times \mathrm{N}_{2} \mathrm{O}^{2}-1.81 \times 10^{-8} \times \mathrm{N}_{2} \mathrm{O}^{3}$ (where $\mathrm{O}_{3}$ is in ppm and $\mathrm{N}_{2} \mathrm{O}$ is in ppb; the uncertainty of the fit is $0.2 \mathrm{ppm})$.

due to halogen-induced chemical ozone destruction [e.g., Tilmes et al., 2003a]. At greater altitudes, above $550 \mathrm{~K}$ $\left(\mathrm{N}_{2} \mathrm{O} \sim 3 \mathrm{ppb}\right.$ at $\left.550 \mathrm{~K}\right)$, both ozone and $\mathrm{N}_{2} \mathrm{O}$ mixing ratios in the BONBON measurements are larger compared to the MkIV measurements in December. This is consistent with increasing mixing of polar with midlatitude air due to the weakening of the polar vortex beginning at those altitudes.

[32] The MIPAS measurements [Friedl-Vallon et al., 2004] on 20 March 2003 show a further decrease in ozone mixing ratios relative to $\mathrm{N}_{2} \mathrm{O}$, consistent with continuing chemical ozone destruction. The measurements above about $550 \mathrm{~K}$ show a pattern very similar to that of the BONBON measurements in early March. The layer between 580 and $700 \mathrm{~K}$ (corresponding to $24-27 \mathrm{~km}$ ) is considered to be influenced by mesospheric air owing to the enhanced $\mathrm{CO}$ mixing ratios (Figure 6). The ozone mixing ratios in this layer have decreased compared to early March.

[33] In the measured ozone- $\mathrm{N}_{2} \mathrm{O}$ relations, the mesospheric data points do not stand out in any of the three balloon profiles measured in the vortex in early 2003 (Figure 7). Therefore additional information from measurements of other gases such as $\mathrm{CO}$ is necessary for identifying mesospheric air masses in the ozone- $\mathrm{N}_{2} \mathrm{O}$ scatterplot (Figure 7). Ozone mixing ratios in these air masses range between 4.8 and $5.6 \mathrm{ppm}$ on 21 January, they are $4.6 \mathrm{ppm}$ on 6 March, they range between 3.6 and $4.2 \mathrm{ppm}$ on 20 March. Such mixing ratios are clearly greater than typical upper stratospheric or mesospheric ozone mixing ratios. That means that the ozone mixing ratios in the stratospheric air masses of mesospheric origin are considerably greater than typical mesospheric ozone mixing ratios $(\sim 2 \mathrm{ppm})$. It is likely that ozone mixing ratios in the air masses of mesospheric origin will have increased chemically during descent owing to the short lifetime of ozone in the mesosphere and in the upper stratosphere. Also, the mesospheric air will mix with surrounding air masses during descent (see section 4). These points are important for assessing the impact of mesospheric intrusions on the accuracy of ozone loss estimates based on ozone-tracer relations.

[34] None of the air masses where the lowest $\mathrm{N}_{2} \mathrm{O}$ (and $\mathrm{CH}_{4}$ ) mixing ratios were observed, neither in January (less than $2 \mathrm{ppb} \mathrm{N}_{2} \mathrm{O}$ at altitudes of $\sim 700 \mathrm{~K}$ ) nor in March 2003 (3-6 ppb $\mathrm{N}_{2} \mathrm{O}$ at altitudes of $\sim 530-550 \mathrm{~K}$ ), show mesospheric characteristics (Figures 3 and 7 , see also the auxiliary material). This indicates that the mesospheric air must have been diluted with stratospheric air during descent. The measurements in March 2003 at $~ 530-550 \mathrm{~K}$, where $\mathrm{N}_{2} \mathrm{O}$ mixing ratios range from 3 to $6 \mathrm{ppb}$, show ozone mixing ratios of 3-3.5 ppm consistent with the balloon measurements in December and January (Figure 7). Therefore, in contrast to the mesospheric layer, these air masses have likely remained largely unmixed and without substantial chemical change over the course of the winter. At an altitude of $\sim 600 \mathrm{~K}$, above the minimum $\mathrm{N}_{2} \mathrm{O}$ values in March, disturbances of the weakening vortex occurred [e.g., Harvey et al., 2002; Manney et al., 2005; Steinhorst et al., 2005] resulting in mixing with air from outside the vortex, thereby causing higher $\mathrm{N}_{2} \mathrm{O}$ mixing ratios.

\subsection{Calculation of Chemical Ozone Loss in the Arctic in March 2003 Based on ILAS-II Measurements}

[35] Comparing an early vortex reference from 16 December 2002 with the ozone-HF relation in February and April measured by the Halogen Occultation Experiment (HALOE) shows the typical signature of chemical ozone loss in the Arctic [Tilmes et al., 2003a]. In agreement with the deduced chemical ozone loss, strong chlorine activation was observed during this winter [Tilmes et al., 2003a]. This picture is corroborated by the MIPAS-B measurements on 20 March 2003. The MIPAS-B ozone- $\mathrm{N}_{2} \mathrm{O}$ relation confirms the earlier balloon measurements at altitudes above 

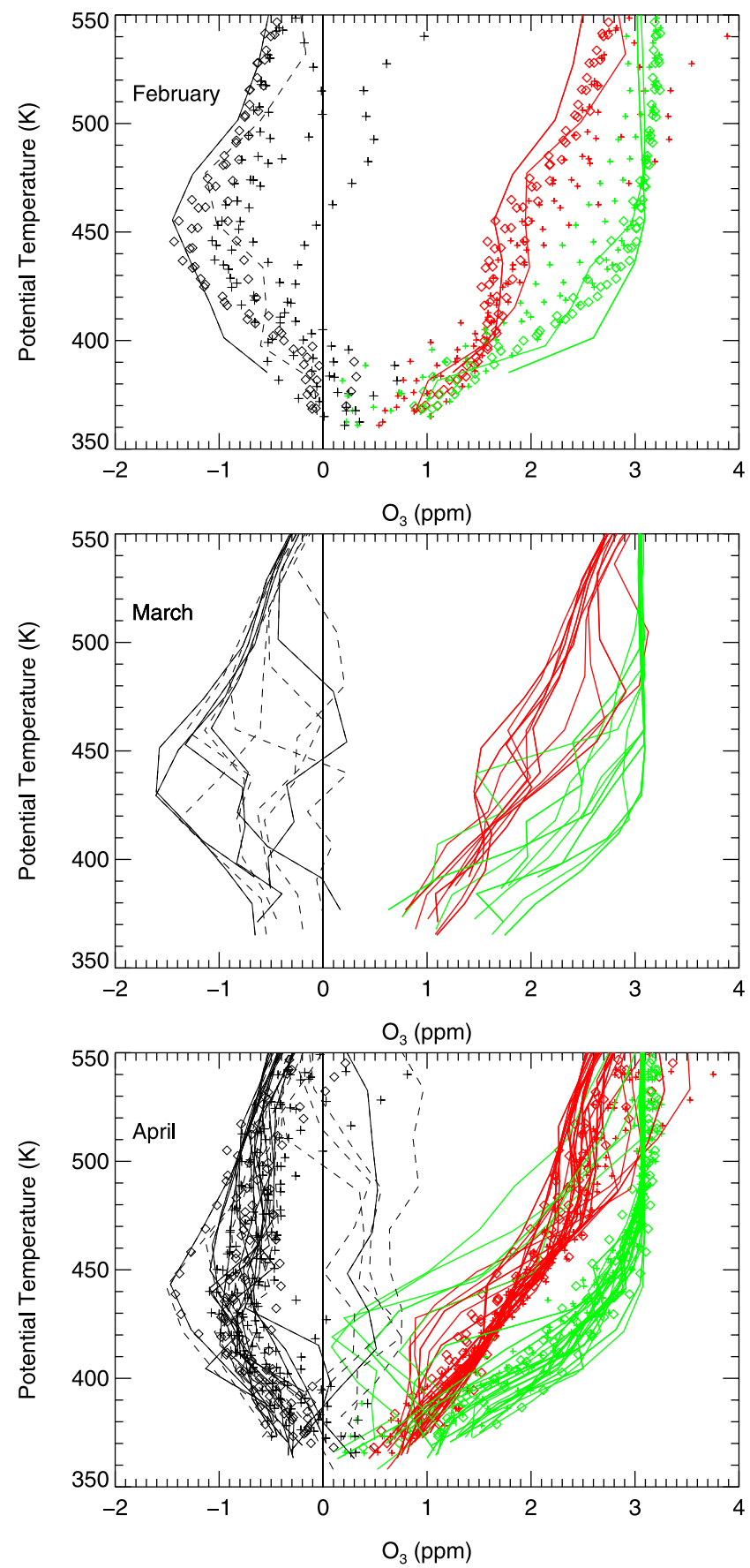

Figure 8. Vertical profiles of measured $\mathrm{O}_{3}$ mixing ratios, red, $\mathrm{O}_{3}$ mixing ratios expected in the absence of chemical change $\left(\hat{\mathrm{O}}_{3}\right)$, green, and calculated $\mathrm{O}_{3}$ loss profiles, black, for (top) February and (middle) March, and (bottom) April in winter 2002/2003. $\hat{\mathrm{O}}_{3}$ was deduced using $\mathrm{HF}$ as the longlived tracer for HALOE measurements and using $\mathrm{N}_{2} \mathrm{O}$ as the long-lived tracer for ILAS-II. HALOE profiles are located inside the vortex core (diamonds) and inside the outer vortex (pluses) in February and April. ILAS-II profiles are located inside the vortex core (solid lines) and inside the outer vortex (dashed lines) between January and April 2003.
$550 \mathrm{~K}$, and additionally shows lower ozone mixing ratios for comparable tracer values of the early winter reference function below $550 \mathrm{~K}$.

[36] Moreover, the ILAS-II instrument aboard ADEOS-II observed the Arctic winter 2002/2003 from 19 January to 19 April 2003 [Nakajima et al., 2006]. The ILAS-II measurements between January and March were obtained during the early turn-on operations during which no major problems occurred [Nakajima, 2006]. On the basis these measurements, chemical ozone loss can be estimated using tracer-tracer correlations.

[37] We derived an early winter reference based on the MkIV ozone- $\mathrm{N}_{2} \mathrm{O}$ relationship from 16 December 2002. Below $550 \mathrm{~K}$, ILAS-II $\mathrm{N}_{2} \mathrm{O}$ mixing ratios are $\sim 40 \mathrm{ppb}$ lower than MkIV observations according to the validation study by Ejiri et al. [2006]. Similarly, ILAS-II $\mathrm{N}_{2} \mathrm{O}$ is $\sim 40$ ppb smaller than $\mathrm{N}_{2} \mathrm{O}$ mixing ratios deduced from HALOE HF measurements using an $\mathrm{HF}$ to $\mathrm{N}_{2} \mathrm{O}$ relation based on MkIV measurements (see the auxiliary material). Therefore a $\mathrm{N}_{2} \mathrm{O}$ offset of $40 \mathrm{ppb}$ is assumed when deriving an early winter reference function from the MkIV data for the ILAS-II observations. In Figure 8 and Table 1, ozone loss derived using ILAS-II observations is compared to the HALOE-based ozone loss reported by Tilmes et al. [2003a].

[38] Here we consider only ILAS-II measurements made inside the polar vortex and group them according to two regions of the vortex: the vortex core and the outer vortex (the area between vortex core and vortex edge). Both the edge of the vortex and the boundary of the vortex core are defined using the gradient of the potential vorticity constrained by wind velocities as a criterion [Tilmes et al., 2003b].

[39] The ILAS-II observations during the early turn-on operations are relatively sparse [Tilmes et al., 2006b]. Therefore only one ILAS-II profile was observed within the outer vortex in January and one in the vortex core in February. Chemical ozone loss derived using these ILAS-II observations is 5-10 Dobson units (DU) larger at 380$550 \mathrm{~K}$ and 4-8 DU smaller at $400-500 \mathrm{~K}$ than the value derived using HALOE measurements, but is still in agreement within the uncertainty of the results. Both ILAS-II and HALOE results show a similar increase of ozone loss values between January and February of 21-24 DU at 380-550 K and $18-22 \mathrm{DU}$ at $400-500 \mathrm{~K}$.

[40] For March, only ILAS-II and MIPAS-B observations are available. The ILAS-II vortex averaged ozone loss in March is less than the vortex-averaged ozone loss in February derived from HALOE observations. However, profiles in March show a much larger variability than in February (the standard deviation of ozone loss profiles is 16 DU for $380-550 \mathrm{~K}$ and $14 \mathrm{DU}$ for $400-500 \mathrm{~K}$ within the polar vortex core). Individual profiles show a rather large chemical ozone loss (55 DU in $380-550 \mathrm{~K}$ and $35 \mathrm{DU}$ in $400-500 \mathrm{~K}$ ). A strong variability of both ozone loss and ozone mixing ratios within the vortex in late March 2003 is consistent with the results of a model study by Groo $\beta$ et al. [2005] (see also the auxiliary material).

[41] Later, in April, a separation of air masses within the vortex is noticeable; a few profiles show large ozone loss values of more than $1.5 \mathrm{ppm}$ at $\sim 440 \mathrm{~K}$ while most profiles show an ozone loss of $0.5-1.0 \mathrm{ppm}$ between $\sim 400$ and $500 \mathrm{~K}$. A few profiles that scatter above the early reference 
Table 1. Arctic Column Ozone Loss in Winter 2002/2003 ${ }^{\mathrm{a}}$

\begin{tabular}{ccccc}
\hline Date & Experiment & Vortex Core & Outer Vortex & Maximum \\
\hline & & $380-550 \mathrm{~K}$ & & \\
19-26 Jan & HALOE & & $23 \pm 9(14)$ & $33 \pm 8$ \\
21 Jan & ILAS-II & & & $42 \pm 6^{\mathrm{b}}$ \\
15-25 Feb & HALOE & $51 \pm 9(6)$ & $26 \pm 9(12)$ & $57 \pm 10$ \\
25 Feb & ILAS-II & & & $63 \pm 10^{\mathrm{b}}$ \\
20-22 Mar & ILAS-II & $37 \pm 11(16)$ & $41 \pm 11(16)$ & $55 \pm 5$ \\
11-19 Apr & HALOE & $49 \pm 10(11)$ & $40 \pm 10(12)$ & $61 \pm 10$ \\
9-19 Apr & ILAS-II & $50 \pm 10(13)$ & $48 \pm 11(12)$ & $67 \pm 11$ \\
& & & & \\
19-26 Jan & HALOE & & & \\
21 Jan & ILAS-II & & & \\
15-25 Feb & HALOE & $43 \pm 6(7)$ & $24 \pm 6(11)$ & $47 \pm 6$ \\
25 Feb & ILAS-II & & & $43 \pm 6^{\mathrm{c}}$ \\
20-22 Mar & ILAS-II & $24 \pm 6(14)$ & $26 \pm 9(6)$ & $35 \pm 6$ \\
11-19 Apr & HALOE & $37 \pm 6(10)$ & $32 \pm 6(9)$ & $52 \pm 6$ \\
9-19 Apr & ILAS-II & $31 \pm 6(10)$ & $33 \pm 6(8)$ & $50 \pm 6$ \\
\hline
\end{tabular}

${ }^{a}$ Column ozone loss in Dobson units in winter 2002/2003 calculated from HALOE measurements using HF as the long-lived tracer [Tilmes et al., 2003a] and ILAS-II measurements using $\mathrm{N}_{2} \mathrm{O}$ as the long-lived tracer. Also reported is the uncertainty of the ozone loss estimate caused by the uncertainty of the early vortex reference and, in brackets, the standard deviation of the computed vortex average loss values. Additionally, the maximum ozone loss of all observations within the respective period is shown.

${ }^{\mathrm{b}}$ One single profile in the outer vortex.

${ }^{\mathrm{c}}$ One single profile in the vortex core.

function are likely influenced by midlatitude air masses during the start of the breakup of the polar vortex. ILAS-II and HALOE ozone loss profiles and calculated loss in column ozone agree very well for April 2003 (Table 1).

\section{Discussion}

[42] In the mesosphere, ozone mixing ratios are typically less than $\sim 2$ ppm because ozone production is balanced by very efficient ozone loss cycles driven by $\mathrm{HO}_{x}$ radicals. At

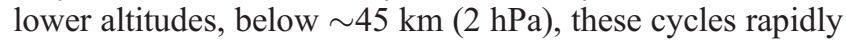
lose their efficiency [e.g., Crutzen et al., 1995; Grooß et al., 1999]. Therefore, when mesospheric air descends, ozone mixing ratios will tend to increase. Also, the increase, i.e., the adjustment to local photochemical equilibrium, will be fast owing to the short chemical lifetime of ozone in the mesosphere and upper stratosphere. When mesospheric air is enhanced in $\mathrm{NO}_{x}$, e.g., caused by energetic particle precipitation [Funke et al., 2005; Randall et al., 2005, 2006; WMO, 2007] one might expect a reduction of ozone in the middle stratosphere due to $\mathrm{NO}_{\mathrm{x}}$ catalyzed ozone loss cycles. However, even under such circumstances, effects of enhanced $\mathrm{NO}_{\mathrm{x}}$ on ozone in the middle stratosphere are not always observed [Randall et al., 2006]. In the Arctic winter 2002-2003, rather inefficient $\mathrm{NO}_{\mathrm{x}}$ downward transport with negligible deposition of $\mathrm{NO}_{\mathrm{x}}$ in the lower and middle stratosphere occurred [Funke et al., 2005]. However, significant ozone loss is noticeable for the unusually strong enhancements of $\mathrm{NO}_{\mathrm{x}}$ in November/December 2003 and January 2004 [Randall et al., 2005; López-Puertas et al., 2005; WMO, 2007], although upper stratospheric ozone mixing ratios (at $40 \mathrm{~km}$ ) are still greater than $5 \mathrm{ppm}$, that is to say clearly greater than mesospheric ozone mixing ratios.
[43] Occasionally, $\mathrm{NO}_{\mathrm{x}}$ in the middle stratosphere is drastically enhanced by solar proton events resulting in long-term (several months) enhancements of stratospheric $\mathrm{NO}_{\mathrm{y}}$ [e.g., Jackman et al., 2006; WMO, 2007]. Because of the enhanced $\mathrm{NO}_{\mathrm{y}}$ upper stratospheric ozone decreases of below $10 \%$ were computed that last for several months after the solar events in the winter polar regions. No strong solar proton events were observed for the time period considered here [e.g., Jackman et al., 2006].

[44] The composition of the air in the mesospheric intrusion is not only determined by chemical change but also by mixing during the descent to the stratosphere. The development of the mesospheric layer started in November 2002 with the descent of mesospheric air that was later cut off by the subsidence of upper stratospheric air triggered by a minor warming that occurred in late December [Engel et al., 2006]. It is remarkable that the mesospheric air was first observed on 21 January 2003 right after the first vortex split and then twice in March 2003 after the second vortex split in mid-February. That means that the signature of the mesospheric layer survived the perturbation of the two vortex splits, although the splits might have contributed to a further dilution of the mesospheric air. The $\mathrm{CO}$ mixing ratios observed in March 2003 are substantially lower than those observed in January 2003 (see Figures 3 and 6 and the auxiliary material) and the tracer values are clearly higher (Figure 7). Ozone mixing ratios in the mesospheric air are lower in March than in January (Figure 7). Thus, if one interprets the lower $\mathrm{CO}$ and greater tracer values in March as the result of mixing, the dilution of mesospheric air would reduce ozone mixing ratios in the mesospheric intrusion.

[45] Intrusions of mesospheric air into the stratosphere have the potential to alter ozone-tracer relations, but as long as these intrusions do not reach the altitudes up to which the tracer relation method [e.g., Müller et al., 1996; Tilmes et al., 2004] is usually employed ( $600 \mathrm{~K})$ they cannot have an impact on ozone loss estimates deduced using this method. Likewise, as long as mesospheric intrusions are clearly identifiable, the effect of the intrusion could be removed from a tracer correlation analysis. Further, intrusions of mesospheric air are only relevant for the calculation of chemical ozone loss estimates using tracer relations if the intrusion reaches the lower stratosphere after the establishment of the early vortex reference relation, that is after late November or December in the Northern hemisphere.

[46] However, assuming that an intrusion of mesospheric air occurs in midwinter down to altitudes below $600 \mathrm{~K}$ and considering the hypothetical (and unrealistic) case that mesospheric air mixes with air in the polar lower stratosphere without any chemical change of the mesospheric ozone mixing ratio, the ozone-tracer relationship would alter; examples of the resulting mixing lines are shown (dotted lines) in the schematic view in Figure 9. Mixing points deduced for this hypothetical case of downward transport of mesospheric ozone without chemical change lie below the stratospheric ozone-tracer relation; therefore, in principle, mixing between stratospheric and mesospheric air could impact ozone loss estimates based on ozone-tracer relations.

[47] For a first rough estimate of the potential impact of intrusions of mesospheric air on polar stratospheric ozone- 


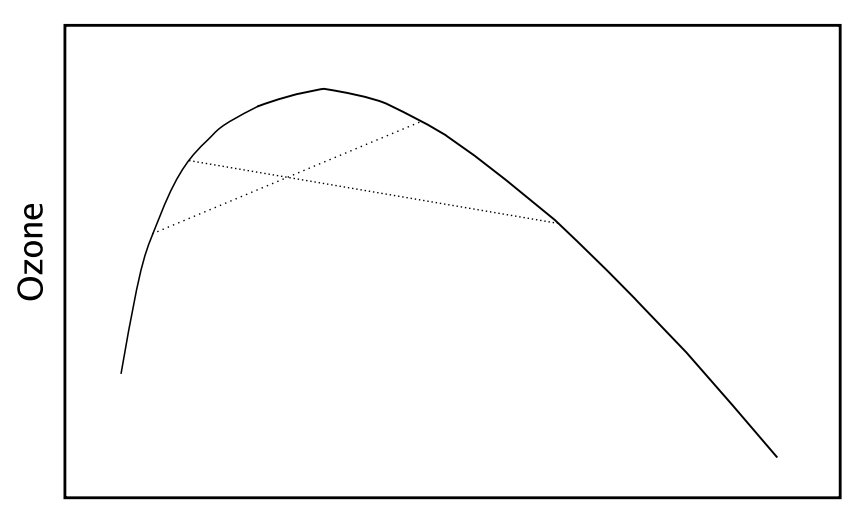

Tracer

Figure 9. Schematic view of the impact of mixing between mesospheric intrusion and stratospheric air on ozone-tracer relations in the stratosphere for the hypothetical (and unrealistic) case of downward transport of mesospheric ozone without chemical change. The solid line indicates the ozone-tracer relation throughout the stratosphere and mesosphere for a tracer with a tropospheric source (such as $\mathrm{CH}_{4}$ or $\mathrm{N}_{2} \mathrm{O}$ ). The dotted lines indicate possible mixing lines between stratospheric and mesospheric air masses at different altitudes.

tracer relations, we assume that the air mass of the entire mesosphere between 1 and $0.01 \mathrm{hPa}$ is "flushed" into (and mixed with) the polar stratospheric air poleward of $60^{\circ}$ between 100 and $10 \mathrm{hPa}$. The mass of this stratospheric polar air is about six times that of the air of the entire mesosphere. Assuming that the air in the entire mesosphere were deposited in the polar stratosphere and displaced an equivalent volume of stratospheric air, the polar stratospheric air would contain 17\% of mesospheric air. Therefore, assuming an ozone mixing ratio of $2 \mathrm{ppm}$ and a methane mixing ratio of $0.1 \mathrm{ppm}$ for the mesospheric air and an ozone mixing ratio of $4 \mathrm{ppm}$ and a methane mixing ratio of $1 \mathrm{ppm}$ for the stratospheric air, stratospheric ozone mixing ratios would change by $9 \%$ and methane mixing ratios by $15 \%$.

[48] However, clearly ozone will change chemically during downward transport (except when in complete darkness). Assuming that the mesospheric ozone mixing ratios were chemically reduced to $1 \mathrm{ppm}$ would mean that stratospheric ozone mixing ratios would change by $13 \%$, and if the ozone mixing ratios were to double during descent then the stratospheric ozone would not be affected at all by the mesospheric intrusion.

[49] A mesospheric fraction of air of $17 \%$ as deduced from this rather crude estimate is a smaller value than that reported by Engel et al. [2006] for the layer of mesospheric air in the Arctic vortex in 2006 but is greater than the value deduced by Ray et al. [2002] for the Arctic polar vortex in winter 1999/2000. The latter study reports a fraction of mesospheric air in the vortex of $2-4 \%$.

[50] However, the assumption that ozone does not change chemically during descent is clearly not correct. Because ozone in the mesosphere and in the upper stratosphere has a short lifetime (less than $\sim 30 \mathrm{~h}$ above $5 \mathrm{hPa}$ or $1000 \mathrm{~K}$ outside the polar night [e.g., Sankey and Shepherd, 2003]) ozone mixing ratios will change chemically during descent by adjusting rapidly toward local photochemical equilibrium. Since ozone mixing ratios increase with decreasing altitude in the upper stratosphere and in the mesosphere (above $\sim 5 \mathrm{hPa}(1000 \mathrm{~K})$ [e.g., Groo $\beta$ and Russell, 2005]), ozone is expected to increase during the descent of mesospheric air, as long as the air parcel receives sufficient sunlight. The ozone mixing ratios should be "frozen in" at the photochemical equilibrium value in the region, where, during poleward and downward transport, the chemical lifetime of ozone becomes substantially longer than the transport timescales.

[51] Ozone lifetimes exceeding a week occur at altitudes of about $10 \mathrm{hPa}$ corresponding to climatological ozone mixing ratios in high latitudes in winter of about $5 \mathrm{ppm}$ [e.g., Groo $\beta$ and Russell, 2005]. This crude estimate agrees with the ozone mixing ratios reported by Engel et al. [2006] for the first sampling of mesospheric air on 21 January 2003 by SPIRALE (see also Figure 7). The concept of a rapid chemical equilibrium that is suddenly frozen in in polar night is, of course, an oversimplification. In reality, a smoother transition between the two regimes will occur. Such a transition could be analyzed (and the resulting ozone mixing ratios better quantified) by a comprehensive model study; such a study, however, is beyond the scope of this paper.

[52] The chemical ozone loss in Arctic winter 2002/2003 deduced here from the ILAS-II measurements can be compared with ozone loss estimates for this winter reported in a number of previous studies. Singleton et al. [2005] find a maximum chemical loss of $1.2 \mathrm{ppm}$ in mid-March at $425 \mathrm{~K}$ in approximate agreement with the ozone loss profiles reported here (Figure 8). The ozone loss deduced for the partial column between 400 and $500 \mathrm{~K}(56 \pm 4 \mathrm{DU})$ using the Match technique [Streibel et al., 2006] is greater than the loss values reported here (Table 1). It is no surprise that chemical ozone loss estimates based on ozone-tracer relations in a winter where the Arctic vortex is strongly impacted by mixing are lower than estimates based on the Match technique. This is so because mixing across the vortex edge will mask chemical ozone loss deduced from ozone-tracer relations [e.g., Müller et al., 2005], whereas Match is designed to exclude this effect. Whether this difference can quantitatively account for the observed discrepancy remains to be shown. The column ozone loss based on the vortex average method in winter 2002/2003 [Christensen et al., 2005] does not agree with our results if an average over the entire vortex is considered; however, the ozone loss reported for the vortex core, within the error bars, is in agreement with the loss deduced here from ILASII measurements. Goutail et al. [2005] report a chemical loss in column ozone by $\sim 19 \pm 4 \%$ by 20 March 2003 . They estimate that 23 DU loss for the partial column $380-$ $550 \mathrm{~K}$ correspond to a loss of $\sim 10 \%$ in column ozone [Goutail et al., 2005, section 4] so that $19 \pm 4 \%$ corresponds to a loss of $\sim 44 \pm 9 \mathrm{DU}$ for the partial column $380-550 \mathrm{~K}$, a value that is in agreement with the chemical ozone loss reported here.

\section{Conclusions}

[53] In Arctic winter 2002/2003 mesospheric air reached altitudes of about $25 \mathrm{~km}(\sim 600 \mathrm{~K})$. This intrusion of 
mesospheric air was clearly identified in three balloon profiles in January and March 2003 by a strong enhancement in $\mathrm{CO}$. $\mathrm{NO}_{y}$ was not enhanced in the intrusion relative to the surrounding air masses as shown by the balloonborne remote sensing measurement on 20 March 2003.

[54] Air of mesospheric origin at lower stratospheric altitudes could potentially impact ozone loss estimates using the ozone tracer relation method. Ozone mixing ratios in mesospheric air are rather low, less than $\sim 2 \mathrm{ppm}$. However, because of the short chemical lifetime of ozone in the upper stratosphere and above, ozone mixing ratios of mesospheric air increase photochemically during downward transport. However, even if the air mass of the entire mesosphere were mixed into the polar lower stratosphere without any chemical change of ozone, polar stratospheric ozone mixing ratios would only change by a few percent.

[55] Observed ozone mixing ratios in air masses influenced by mesospheric air in the lower stratosphere in January and March 2006 are greater than those in the surrounding stratospheric air and clearly greater than those found in the early vortex reference relation employed to deduce chemical ozone loss. Thus, if mesospheric air masses were to reach the lower stratosphere and mix strongly enough so that they could no longer be identified, ozone mixing ratios in the lower stratosphere would increase so that the chemical ozone loss signal would be underestimated. Therefore we conclude that intrusions of mesospheric air are unlikely to have a significant impact on ozone loss estimates based on the ozone-tracer relation method and, if they were to have an effect, could only lead to an underestimate of chemical ozone loss.

[56] We combined measurements of ozone and $\mathrm{N}_{2} \mathrm{O}$ by the MkIV instrument on 16 December 2002 with ILAS-II satellite measurements to deduce chemical ozone loss in the Arctic vortex in March and April 2003. The estimated ozone loss for April is in agreement with previous estimates that were based on HALOE measurements [Tilmes et al., 2003a]. We find an average chemical ozone loss in the vortex core for the partial column $380-550 \mathrm{~K}$ of $37 \pm 11 \mathrm{DU}$ units in March and of $50 \pm 10$ DU in April 2003.

[57] Acknowledgments. We thank Bärbel Vogel, Paul Konopka, Gabi Stiller, and Bernd Funke for helpful discussions. Thanks are due to three anonymous reviewers for very helpful comments. We further gratefully acknowledge all members of the science team of the Improved Limb Atmospheric Spectrometer (ILAS-II) led by Y. Sasano and H. Nakajima for processing the ILAS-II version 1.4 data. ILAS-II was developed by the Ministry of the Environment, Japan (MOE), and was on board the ADEOSII satellite launched by the Japan Aerospace Exploration Agency (JAXA). ILAS-II data were processed at the ILAS-II Data Handling Facility, National Institute for Environmental Studies (NIES).

\section{References}

Christensen, T., et al. (2005), Vortex-averaged Arctic ozone depletion in the winter 2002/2003, Atmos. Chem. Phys., 5, 131-138.

Crutzen, P. J., J.-U. Grooß, C. Brühl, and R. Müller (1995), A reevaluation of the ozone budget with HALOE UARS data: No evidence for the ozone deficit, Science, 268, 705-708.

Curtius, J., et al. (2005), Observations of meteoric material and implications for aerosol nucleation in the winter Arctic lower stratosphere derived from in situ particle measurements, Atmos. Chem. Phys., 5, 3053-3069.

de Zafra, R., and G. Muscari (2004), CO as an important high-altitude tracer of dynamics in the polar stratosphere and mesosphere, J. Geophys. Res., 109, D06105, doi:10.1029/2003JD004099.

Ejiri, M. K., et al. (2006), Validation of the Improved Limb Atmospheric Spectrometer-II (ILAS-II) version 1.4 nitrous oxide and methane profiles, J. Geophys. Res., 111, D22S90, doi:10.1029/2005JD006449.
Engel, A., et al. (2006), Observation of mesospheric air inside the Arctic stratospheric polar vortex in early 2003, Atmos. Chem. Phys., 6, 267-282. Friedl-Vallon, F., G. Maucher, A. Kleinert, A. Lengel, C. Keim, H. Oelhaf, H. Fischer, M. Seefeldner, and O. Trieschmann (2004), Design and characterization of the balloon-borne Michelson Interferometer for Passive Atmospheric Sounding (MIPAS-B2), Appl. Opt., 43, 3335-3355.

Funke, B., M. López-Puertas, S. Gil-López, T. von Clarmann, G. P. Stiller, H. Fischer, and S. Kellmann (2005), Downward transport of upper atmospheric $\mathrm{NO}_{x}$ into the polar stratosphere and lower mesosphere during the Antarctic 2003 and Arctic 2002/2003 winters, J. Geophys. Res., 110, D24308, doi:10.1029/2005JD006463.

Funke, B., et al. (2006), Carbon monoxide measurements from MIPAS on ENVISAT, Geophys. Res. Abstr., 8, 10,642.

Goutail, F., et al. (2005), Early unusual ozone loss during the Arctic winter 2002/2003 compared to other winters, Atmos. Chem. Phys., 5, 665-677.

Grooß, J.-U., and J. M. Russell (2005), Technical note: A stratospheric climatology for $\mathrm{O}_{3}, \mathrm{H}_{2} \mathrm{O}, \mathrm{CH}_{4}, \mathrm{NO}_{\mathrm{x}}, \mathrm{HCl}$ and $\mathrm{HF}$ derived from HALOE measurements, Atmos. Chem. Phys., 5, 2797-2807.

Grooß, J.-U., R. Müller, G. Becker, D. S. McKenna, and P. J. Crutzen (1999), The upper stratospheric ozone budget: An update of calculations based on HALOE data, J. Atmos. Chem., 34, 171-183.

Grooß, J.-U., G. Günther, R. Müller, P. Konopka, S. Bausch, H. Schlager, C. Voigt, C. M. Volk, and G. C. Toon (2005), Simulation of denitrification and ozone loss for the Arctic winter 2002/2003, Atmos. Chem. Phys., 5, 1437-1448.

Harvey, V., R. Pierce, T. Fairlie, and M. Hitchman (2002), A climatology of stratospheric polar vortices and anticyclones, J. Geophys. Res., 107(D20), 4442, doi:10.1029/2001JD001471.

Huret, N., M. Pirre, A. Hauchecorne, C. Robert, and V. Catoire (2006), On the vertical structure of the stratosphere at midlatitudes during the first stage of the polar vortex formation and in the polar region in the presence of a large mesospheric descent, J. Geophys. Res., 111, D06111, doi:10.1029/2005JD006102.

Jackman, C. H., M. T. Deland, G. J. Labow, E. L. Fleming, and M. LópezPuertas (2006), Satellite measurements of middle atmospheric impacts by solar proton events in solar cycle 23, Space Sci. Rev., 125(1-4), 381391.

Konopka, P., et al. (2007), Ozone loss driven by nitrogen oxides and triggered by stratospheric warmings may outweigh the effect of halogens, J. Geophys. Res., 112, D05105, doi:10.1029/2006JD007064.

Kouker, W., A. Beck, H. Fischer, and K. Petzoldt (1995), Downward transport in the upper stratosphere during the minor warming in February 1979, J. Geophys. Res., 100(D6), 11,069-11,084.

Lemmen, C., M. Dameris, R. Müller, and M. Riese (2006a), Chemical ozone loss in a chemistry-climate model from 1960 to 1999, Geophys. Res. Lett., 33, L15820, doi:10.1029/2006GL026939.

Lemmen, C., R. Müller, P. Konopka, and M. Dameris (2006b), Critique of the tracer-tracer correlation technique and its potential to analyse polar ozone loss in chemistry-climate models, J. Geophys. Res., 111, D18307, doi:10.1029/2006JD007298.

López-Puertas, M., B. Funke, S. Gil-López, T. von Clarmann, G. P. Stiller, M. Höpfner, S. Kellmann, H. Fischer, and C. H. Jackman (2005), Observation of $\mathrm{NO}_{x}$ enhancement and ozone depletion in the Northern and Southern hemispheres after the October-November 2003 solar proton events, J. Geophys. Res., 110, A09S43, doi:10.1029/2005JA011050.

Manney, G. L., M. L. Santee, N. J. Livesey, L. Froidevaux, W. G. Read, H. C. Pumphrey, J. W. Waters, and S. Pawson (2005), EOS Microwave Limb Sounder observations of the Antarctic polar vortex breakup in 2004, Geophys. Res. Lett., 32, L12811, doi:10.1029/2005GL022823.

Michelsen, H. A., G. L. Manney, M. R. Gunson, and R. Zander (1998), Correlations of stratospheric abundances of $\mathrm{NO}_{y}, \mathrm{O}_{3}, \mathrm{~N}_{2} \mathrm{O}$, and $\mathrm{CH}_{4}$ derived from ATMOS measurements, J. Geophys. Res., 103(D21), 28,347-28,360.

Müller, R., P. J. Crutzen, J.-U. Grooß, C. Brühl, and A. F. Tuck (1996), Chlorine activation and ozone depletion in the Arctic vortex: Observations by the Halogen Occultation Experiment on the Upper Atmosphere Research Satellite, J. Geophys. Res., 101(D7), 12,531-12,554.

Müller, R., S. Tilmes, P. Konopka, J.-U. Grooß, and H.-J. Jost (2005), Impact of mixing and chemical change on ozone-tracer relations in the polar vortex, Atmos. Chem. Phys., 5, 3139-3151.

Nakajima, H. (2006), Preface to special section on ILAS-II: The Improved Limb Atmospheric Spectrometer-II, J. Geophys. Res., 111, D20S90, doi:10.1029/2006JD007412.

Nakajima, H., et al. (2006), Characteristics and performance of the Improved Limb Atmospheric Spectrometer-II (ILAS-II) on board the ADEOS-II satellite, J. Geophys. Res., 111, D11S01, doi:10.1029/ 2005JD006334.

Plumb, R. A., D. W. Waugh, and M. P. Chipperfield (2000), The effects of mixing on tracer relationships in the polar vortices, J. Geophys. Res., 105(D8), 10,047-10,062. 
Randall, C. E., et al. (2005), Stratospheric effects of energetic particle precipitation in 2003-2004, Geophys. Res. Lett., 32, L05802, doi:10.1029/2004GL022003.

Randall, C. E., V. L. Harvey, C. S. Singleton, P. F. Bernath, C. D. Boone, and J. U. Kozyra (2006), Enhanced $\mathrm{NO}_{x}$ in 2006 linked to strong upper stratospheric Arctic vortex, Geophys. Res. Lett., 33, L18811, doi:10.1029/2006GL027160.

Ray, E. A., F. L. Moore, J. W. Elkins, D. F. Hurst, P. A. Romashkin, G. S. Dutton, and D. W. Fahey (2002), Descent and mixing in the 1999-2000 northern polar vortex inferred from in situ tracer measurements, J. Geophys. Res., 107(D20), 8285, doi:10.1029/2001JD000961.

Rex, M., et al. (1999), Subsidence, mixing, and denitrification of Arctic polar vortex air measured during POLARIS, J. Geophys. Res., 104(D21), 26,611-26,624.

Rex, M., et al. (2002), Chemical depletion of Arctic ozone in winter 1999/ 2000, J. Geophys. Res., 107(D20), 8276, doi:10.1029/2001JD000533.

Rinsland, C. P., R. J. Salawitch, M. R. Gunson, S. Solomon, R. Zander, E. Mahieu, G. M. J. A.Newchurch, F. W. Irion, and A. Y. Chang (1999), Polar stratospheric descent of $\mathrm{NO}_{y}$ and $\mathrm{CO}$ and Arctic denitrification during winter 1992-1993, J. Geophys. Res., 104(D1), 1847-1861.

Rothman, L., et al. (2005), The HITRAN 2004 molecular spectroscopic database, J. Quant. Spectrosc. Radiat. Transfer, 96(2), 139-204.

Salawitch, R. J., et al. (2002), Chemical loss of ozone during the Arctic winter of 1999/2000: An analysis based on balloon-borne observations, J. Geophys. Res., 107(D20), 8269, doi:10.1029/2001JD000620.

Sankey, D., and T. G. Shepherd (2003), Correlations of long-lived chemical species in a middle atmosphere general circulation model, J. Geophys. Res., 108(D16), 4494, doi:10.1029/2002JD002799.

Singleton, C. G., et al. (2005), 2002-2003 Arctic ozone loss deduced from POAM III satellite observations and the SLIMCAT chemical transport model, Atmos. Chem. Phys., 5, 597-609.

Steinhorst, H.-M., P. Konopka, G. Günther, and R. Müller (2005), How permeable is the edge of the Arctic vortex: Model studies of winter 19992000, J. Geophys. Res., 110, D06105, doi:10.1029/2004JD005268.

Streibel, M., et al. (2006), Chemical ozone loss in the Arctic winter 2002/ 2003 determined with Match, Atmos. Chem. Phys., 6, 2783-2792.

Sugita, T., Y. Kondo, H. Nakajima, U. Schmidt, A. Engel, H. Oelhaf, G. Wetzel, M. Koike, and P. A. Newman (1998), Denitrification observed inside the Arctic vortex in February 1995, J. Geophys. Res., 103(D13), $16,221-16,234$

Tilmes, S. (2004), Chemical ozone loss in the Arctic polar stratosphere, technical report, Inst. for Chem. and Dyn. of the Geosphere, Jülich, Germany.

Tilmes, S., R. Müller, J.-U. Grooß, M. Höpfner, and G. C. Toon (2003a), Very early chlorine activation and ozone loss in the Arctic winter 20022003, Geophys. Res. Lett., 30(23), 2201, doi:10.1029/2003GL018079.

Tilmes, S., R. Müller, J. Grooß, D. S. McKenna, and Y. Sasano (2003b), Calculation of chemical ozone loss in the Arctic winter 1996-1997 using ozone-tracer correlations: Comparison of Improved Limb Atmospheric Spectrometer (ILAS) and Halogen Occultation Experiment (HALOE) results, J. Geophys. Res., 108(D2), 4045, doi:10.1029/2002JD002213.
Tilmes, S., R. Müller, J.-U. Grooß, and J. M. Russell (2004), Ozone loss and chlorine activation in the Arctic winters 1991-2003 derived with the tracer-tracer correlations, Atmos. Chem. Phys., 4(8), 2181-2213.

Tilmes, S., R. Müller, A. Engel, and M. Rex (2006a), Chemical ozone loss in the Arctic and Antarctic stratosphere between 1992 and 2005, Geophys. Res. Lett., 33, L20812, doi:10.1029/2006GL026925.

Tilmes, S., R. Müller, J.-U. Grooß, R. Spang, T. Sugita, H. Nakajima, and Y. Sasano (2006b), Chemical ozone loss and related processes in the Antarctic winter 2003 based on Improved Limb Atmospheric Spectrometer (ILAS)-II observations, J. Geophys. Res., 111, D11S12, doi:10.1029/2005JD006260.

Tilmes, S., D. E. Kinnison, R. R. Garcia, R. Müller, F. Sassi, D. R. Marsh, and B. A. Boville (2007), Evaluation of Heterogeneous Processes in the Polar Lower Stratosphere in WACCM3, J. Geophys. Res., doi:10.1029/ 2006JD008334, in press.

Toon, G. C., et al. (1999), Comparison of MkIV balloon and ER-2 aircraft measurements of atmospheric trace gases, J. Geophys. Res., 104, $26,779-26,790$.

Velazco, V., et al. (2007), Annual variation of strato-mesospheric carbon monoxide measured by ground-based Fourier transform infrared spectrometry, Atmos. Chem. Phys., 7, 1305-1312.

Vitt, F., T. Cravens, and C. Jackman (2000), A two-dimensional model of thermospheric nitric oxide sources and their contributions to the middle atmospheric chemical balance, J. Atmos. Sol. Terr. Phys., 62, 653-667.

Waugh, D. W., and W. J. Randel (1999), Climatology of Arctic and Antarctic polar vortices using elliptical diagnostics, J. Atmos. Sci., 56, $1594-$ 1613.

Wetzel, G., et al. (2006), Intercomparison and validation of ILAS-II version 1.4 target parameters with MIPAS-B measurements, J. Geophys. Res., 111, D11S06, doi:10.1029/2005JD006287.

World Meteorological Organisation (WMO) (2007), Scientific assessment of ozone depletion: 2006, Rep. 50, Global Ozone Res. and Monit. Proj., Geneva, Switzerland.

V. Catoire, N. Huret, and M. Pirre, Laboratoire de Physique et Chimie de l'Environnement, CNRS-Université d'Orléans (UMR 6115) 3A, Avénue de la Rechèrche Scientifique, F-45071 Orléans cedex 2, France.

A. Engel, Institut für Atmosphäre und Umwelt, Johann Wolfgang Goethe-Universität, D-60325 Frankfurt, Germany.

J.-U. Grooß and R. Müller, Forschungszentrum Jülich, ICG-1, D-52425 Jülich, Germany. (ro.mueller@fz-juelich.de)

H. Nakajima, Atmospheric Environment Division, NIES, 16-2 Onogawa, Tsukuba, 305-8506, Japan.

H. Oelhaf and G. Wetzel, Forschungszentrum Karlsruhe, IMK-ASF, P.O. Box 3640, D-76021 Karlsruhe, Germany.

S. Tilmes, Atmospheric Chemistry Division, NCAR, P.O. Box 3000, Boulder, CO 80307, USA.

G. C. Toon, Jet Propulsion Laboratory, California Institute of Technology, 4800 Oak Grove Drive, Pasadena, CA 91109, USA. 